\title{
THE ESSENCE OF HUMAN IN BEDIL'S CREATION
}

\section{Nargiza Shoalieva}

Candidate of Philological Sciences, Senior Lecturer Department Of Uzbek Language And Oriental Classical Literature International Islamic Academy Of Uzbekistan

\section{ABSTRACT}

Mirza Abdulkadir Bedil is a Persian-speaking poet, prose writer, philosopher and Indian thinker, very popular among the peoples of Central Asia and Afghanistan. In his work, Bedil analyzes the main part of the works of art and literature of Persian and Tajik poets from Rudaki to Jami and the literary and philosophical ideas of Sanayi, Attar, Jalaliddin Rumi and Ibn al-Arabi. The ancient philosophy of ancient Iran, Greece, India and Arabia laid the foundation for the development of literary and philosophical ideas, and as a result of relying on the achievements of the past, Mirza Bedil strengthened his philosophical thought.

KEYWORDS: - Bedil, poet, intellect, contemplation, philosophy, human, source.

\section{INTRODUCTION}

Scientists call Bedil-Abulmaani, which means father of essences. Bedil's father and grandfather were originally from the Barlos clan of Samarkand, on the outskirts of Samarkand, and the Uzbek khans and Iranian Safavids fled to India during the religious uprisings. Born in Patna in 1644 to a military family near Azimabad, India, Bedil died on December 5, 1720 in Delhi. Sadriddin Ayni considered the addition of the word "Mirzo" to the name of Bedil and his relatives as proof that one of his ancestors was a great leader.

He traveled extensively throughout India, and lived in Delhi from 1685 until the end of his life. Examples of his work have been preserved in Persian. Fluent in Arabic, Persian, Hindi, and Urdu, he studied Oriental literature, Greek philosophy, and in particular Aristotle's philosophy.

\section{THE MAIN FINDINGS AND RESULTS}

The philosopher considers the mind to be divine, elevates it to a higher level, and evaluates man with the mind as well. "The essence of faith is abstract without a mirror, and the water without a spring is indestructible". That is, foolish faith is as baseless, abstract, and foolish shame as glassless ore, and as ignorant as water without a source. (Ibrahim Muminov. Mirza Bedil, 1964: 68.) When a poetthinker understands philosophers, he understands the wise, the creators of wisdom.

In the teachings of Eastern sages, wisdom is associated with human happiness. Bedil's teaching 
CURRENT RESEARCH JOURNAL OF PHILOLOGICAL SCIENCES 2(9): 110-

116, September 2021

DOI: https://doi.org/10.37547/philological-crjps-02-09-24

ISSN 2767-3758

(C)2021 Master Journals

\section{Crossref do}

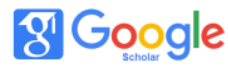

Accepted25 $5^{\text {th }}$ September, 2021 \& Published $30^{\text {th }}$ September, 2021

is no exception. For example, Abu Nasr al-Farabi interprets knowledge, wisdom, and reason as the primary means of achieving happiness. According to him, with the help of reason and science, it is possible to rise to such a level of spirituality that this spirituality will serve humanity even after the death of generations. (From the history of sociophilosophical thought in Uzbekistan, 1995: 51) There are many such ideas given to the human mind by the sages. From this it follows that the essence of wisdom is reason - thinking and knowledge. Indeed, the mind is the core of wisdom, maturity, goodness. If the mind is enriched with knowledge, it will be an important factor in raising human spirituality to another level. The proof of this we see more clearly in Bedil's teaching. Mirza Bedil emphasizes that science is the true jewel of man, and puts forward the idea that in order for man to understand the secrets of nature, he must be knowledgeable and diligent.

"Just as an artist cannot draw a picture of anything without a pencil," says Bedil, "without knowledge a person cannot know the truth of anything". What they know without knowledge is utter ignorance. Science is the guarantor of the event everywhere, the proof of the effect of victory. Science is one of the means of making a person happy. When a person is given ignorance, the grain becomes a husk, and with knowledge, a person can turn the husk into a grain. Whoever lights a candle in the field of science, his name will live forever." (Ibrahim Muminov. Mirza Bedil. 1964: 64).

The great thinker says in his book "Irfon" that science is the jewel of humanity. He writes that human perfection and virtue are with knowledge, and writes the following:

To fazlu hunarga bezanmay inson, Biron baxt eshigi ochilmish qachon? Javhar bilan po'lat bo'lur jo'n temir, Ilmsiz o'z jinsidan chiqmog'i gumon.
Meaning:

Without engaging in human activity

When will the door to happiness open?

Steel with ore is iron wool,

It is doubtful that it will come out of its shell without knowledge. (Mirza Abdulkadir Bedil. Rubaiyat, 1964: 44.)

Bedil calls man to acquire knowledge, warning that he can attain happiness through knowledge. He also values science and wisdom, emphasizing that a person without knowledge cannot comprehend his true nature. The poet says the same thing about science and wisdom:

Gul az in bog'i fayz agar bo'yi,

Damad az xoru xas Arastue.

Meaning:

Flowers from this garden of grace if the smell,

The bridegroom of Aristotle. (Ibrahim Muminov. Mirza Bedil, 1964: 18).

That is, the knowledge of this garden (of this world) is beneficial if you smell its flower, and every thorn and thorn of it can be found as the source of the thoughts and beauty of philosophers like Aristotle.

Mirza Bedil, referring to wisdom, wisdom, knowledge and enlightenment, emphasizes the concept of "example". In Bedil's eyes, he likens those who do not learn from good things to the door of the house, to the hole in the roof. He says this in his book The Four Elements: The eyes of a person who is awake in distress are like a house with a closed door. If such a person seems to be a little careless with destruction, his body should be set on fire. However, if some sages keep secret what they have witnessed and learned, it is better to give their land to the wind. Life consists of vigilance, which must be subordinated to the service of a dear life. Sleep means death, it is the companion of the dead. At the heart of the movement of the living are hidden different colors. That's why you can embroider the pictures you want in your mind like Behzod's brush. The goal is to remember to look at these things with an exemplary eye, and as long as 
CURRENT RESEARCH JOURNAL OF PHILOLOGICAL SCIENCES 2(9): 110-

116, September 2021

DOI: https://doi.org/10.37547/philological-crjps-02-09-24

ISSN 2767-3758

(C)2021 Master Journals

\section{Crossref do}

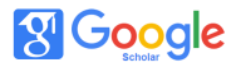

Accepted25 $5^{\text {th }}$ September, 2021 \& Published 30 ${ }^{\text {th }}$ September, 2021

you have the opportunity, watch the world, its virtues, and enjoy them. (Mirza Abdulqadir Bedil. Four elements. 127).

Hayotdan olmasa ibrat u ko'z ko'r, Asalda bo'lmasa shirinlik u sho'r.

O'zgarib turmagan libos kafandir,

O’zgarish bo'lmagan xona qaro go'r.

Meaning:

If the eye does not learn from life, it is blind,

If there is no sweetness in the honey, it is salty.

The unchanging garment is the shroud,

The room is a black grave without change. (Mirza

Abdulkadir Bedil. Rubaiyat.1974: 24).

It is clear that the concept of example is also important in raising human knowledge to another level. Through this concept, the idea of changing the world, of perfecting the sciences, was put forward by the scientist.

There is one aspect of the philosopher's philosophical, social ideal that draws attention to the closeness of the thinker to the Sufi sages, his constant influence on the philosophical worldview. It should be noted that Mirzo Bedil also used the teachings of mysticism in the matter of man and his essence. As we compare Bedi's philosophy more with Farididdin Attar's views, this is also the case in the human case. Attor's "Javhar uz-zot" first describes the unity of all spiritual and material worlds, that is, the world of unity and the power of the absolute Creator. Then the place of man in this world of unity, the essence of the human being, the ways of knowing oneself and the Creator, the suffering of suffering, that is, the purification of the soul and self-realization; the mystery of monotheism is explained in detail - the existence of the body, the world, the struggle with the nafs, the joining of the Truth through the stage of tajridu tafrid. (Farididdin Attor. Ilohiynoma. 1994: 73).

While Bedil emphasizes that man was created in the highest status among the creatures of the universe, he wants to make people worthy of this honorable title, regardless of race or position in society. It is true that he mentions from a religious-mystical point of view that it is easy for a person to quickly detach from his original position in the "original pearl" - the divine realm - and move to a lower, that is, "earthly" material life. In fact, a diamond never turns to dust and that is why it is a precious gemstone. However, Bedil wants man to be as rare as a pearl in morality.

According to Bedil, man is a miracle, but at the same time a source of strife. He therefore draws attention to the need to take into account these two different natures in man. Bedil emphasizes the greatness of man, his mental ability, his ability to do many things, his speech, his mind, his intellect, and his ability to distinguish himself from other creatures. the poet sought to shed light on the existence of negative vices along with the noble moral and spiritual qualities in man.

In his works "Irfon" and "Chor Unsur", Bedil introduces the concept of "absolute sea" (sea of perfection) in explaining human existence. By "absolute sea," Bedil refers to an absolute being based on divine power. Mankind came into being from this absolute being with power and will:

Bahri mutlaq issiq mavj urdi shunday,

Bo'ldik o'zimizdan a'loga muhtoj.

Meaning:

The sea was absolutely so hot,

We needed someone better than ourselves. (Mirzo Abdulqadir Bedil, 1974: 42).

The philosopher sees in man the nature and essence of the whole universe. That is, man is so honored that Allah created all beings for man and made the angels worship him. He placed all wisdom and knowledge in his heart. Bedil describes it that way: Kavnu makon gulest ba domoni himmatat, Xudro agar ihota kuni, charxi digarū.

Olam hama musaxxari amri zamiri tust 
CURRENT RESEARCH JOURNAL OF PHILOLOGICAL SCIENCES 2(9): 110-

116, September 2021

DOI: https://doi.org/10.37547/philological-crjps-02-09-24

ISSN 2767-3758

(C)2021 Master Journals

\section{Crossref do}

\section{Google}

Accepted25th September, 2021 \& Published $30^{\text {th }}$ September, 2021

Ey bexabar, tu az chi xabarho musaxxari.

Meaning:

Because of your generosity and zeal, the world has blossomed,

If you can play yourself, you will be a special world. The whole world has obeyed your command.

0 ignorant one, why are you chasing fantasies?! (Shavkat Shukurov. Mirzo Bedil's poetic heritage. 1979: 71).

We again compare the above-mentioned ideas in Bedil's philosophy with the views of Farid al-Din Attar: "Though in the end your place is under the ground, but your pure soul is pure from the dust (your soul is holy). Remember that your pearl is the worship of angels. You have the crown of the caliphate on your head, you are the child of the caliph, that is, you are the vicegerent of Allah on earth. If you come down from heaven, that flower is the path to heaven." (Farididdin Attor. Ilohiynoma, 1994: 10).

Jabroil parvozi oshyoningda. (Gabriel's flight is in the oshiyon.) (From the Treasures of Eastern Thought. 1986: 97).

According to Bedil, man is helpless because he does not know that he is such a great power, and emphasizes that all calamities fall on his head, becoming a source of error. Bedil draws attention to the concept of imitation as the reason why man becomes ignorant of his own power, a source of error.

The second important aspect in the analysis of human nature is imitation, according to Bedil's interpretation. Bedil commented on the imitation somewhere, "O Bedil, what have you found in search of the market of understanding - have you found a scale that weighs heavily on the conscience? That is why living in imitation without knowing its power is a prison, and those who really want to live must get rid of this dark prison (Hamidulla
Boltaboev. Fitrat - Bedilshunos. 2005: 47). According to Bedil, a dark, dungeon is an imitation. In Bedil's view, man admits weakness because he does not know that he is a great being. One of the reasons that deprives man of his power, spiritual and natural development is imitation.

Bedil seeks to explain that the unconscious, blind follow-up of people, their obedience to rituals, to pagans, is an obstacle to his great deeds. He sees the true power of human beings in the pursuit of knowledge and enlightenment, avoiding imitation.

Bedil shows that man has the greatest, the highest intellect, the power of thinking, the power of the heart. Bedil understands that another reason that unites imitation in human nature is a misunderstanding of religion. Therefore, the thinker believed that not understanding the essence of religion as its third important aspect in the analysis of human nature was a misinterpretation of the religious view. (Hamidulla Boltaboev. Fitrat Bedilshunos. 2005: 48).

Bedil opposes the dry preaching and formal use of the words of God. In his view, the true nature of religion must be explained, that is, the attempt to deify people by frightening them with hell and encouraging them with heaven gradually turns the words of God into irrational myths, amusing narrations, and people become enchanted by these myths and unable to comprehend their true nature. In one verse, Bedil refers to the lectures and sermons of the imam-sheikhs in the mosque:

To chunbishi tori nafas afsonatiroz ast,

Bedil, ba kamandi ragi xob ast dili mo.

Meaning:

As the breath moves, the legend,

Bedil, captures our souls.

The word "ragi hob" (literally "sonnaya artery" in the dictionary) means that a person falls into a state of anesthesia if he is massaged or touched. (Ismail Bekjan. Bedil, modeled on Navoi, 2007: 4) We know that Bedil's predecessor Alisher Navoi in his poetic 
CURRENT RESEARCH JOURNAL OF PHILOLOGICAL SCIENCES 2(9): 110-

116, September 2021

DOI: https://doi.org/10.37547/philological-crjps-02-09-24

ISSN 2767-3758

(C)2021 Master Journals

\section{Crossref doi) 81 Google}

Accepted25 ${ }^{\text {th }}$ September, 2021 \& Published 30 ${ }^{\text {th }}$ September, 2021

thoughts emphasized the sleep-inducing nature of the legend:

Shomi hajrim sharhi elni bexud etsa ne ajab,

Uyqu keltirmakdurur xosiyati afsonaning.

Meaning;

It is not surprising that the commentary of Shami Hajrim is useless.

The nature of the myth is to bring sleep.

The philosophical and social meaning of the verse is as follows: As long as we are alive, the nature around us and the society in which we live reveal all kinds of events, and we are confused and unable to comprehend them.

The second meaning of the verse is that one cannot rely on and believe in anything in this false world, because life, beauty, and eating and drinking are all temporary in this world. They were created to deceive us until we left for our original space. From this wisdom of Bedil, many concepts of educational significance emerge. For example, a person should therefore always be vigilant, not be greedy for this temporary world, and not engage in evil deeds out of selfishness.

Hence, Bedil calls on man to renounce imitation and blind adherence to religious beliefs by relying on his own power.

According to Bedil's story, on the side of Bihar (in the province where the poet was born and raised) lived a wealthy merchant. She has a seven-year-old daughter named Rajivanti, and according to Indian tradition, she is engaged to a son. However, an unexpected event occurs and the young man dies. This terrible news is conveyed to Rajivanti without informing the girl's descendants. At the time of the bridegroom's funeral, Rajivanti takes a candle from the shelf and sets himself on fire. Everyone is aware of this and seeks to clear the grass and save the girl. But the opportunity was missed, and Rajivanti was sold (sacrificed) according to Brahmanic tradition. Bedil thinks of himself as a man who sympathizes with the fate of trafficked women and as a thinker who fights against imitation, a fierce enemy of this habit.

The poet, who is not indifferent to human destiny, considers it his duty to recite the word of the heart. Because man is the soul. The light of God is reflected in the heart. Bedil, in turn, says so to those who do not understand the secrets of the mind:

Yor quchoqda bo'lsa hamki, kimdir u, bilmaymiz hech,

Oynadek oydin agarchi, bag'rimiz - bo'stonimiz.

Meaning:

Even if the friend is in your arms, someone he is, we do not know,

Although it is as clear as a mirror, our heart is our garden. (Matnazar Abdulhakim. Holy visit. 1991: 28).

While seeking the Truth in the hearts of the people, Bedil says that the tawaf should begin with that: No matter where you go or where you visit, the conversation is lively. " (Mirza Abdulkadir Bedil. Ghazals and poems, Hijri 1333: 3)

Malono is one of Rumi's famous bytes in this regard:

هم مسجد و هم كعبه و هم قبله بهانه است

دقت بكنى نور خدا داخل خانه است فئ

The mosque, the Kaaba and the Qibla are an excuse

Notice that the light of God is in the house

در مسجد و در كعبه به دنبال جه هستى إنى

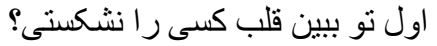

What are you looking for in the Masjidu Kaaba?

Blind first, don't you break any heart?

اينكونه جر ا در يبى اثبات خداييج؟

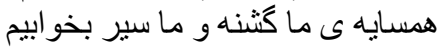

How long are we going to prove God?

Even our neighbor is hungry, we go to bed

در خلقت مار از و معماى خدا جِيست؟

انسان خودش آيينه يك كعبه مكر نيست

What is the secret of God in our bodies?

Isn't man himself the mirror of the Ka'bah?

برخيز و كمى كعبه ى آمال خودت باش باش

جنحى به نقابت بزن و مال خودت بالش

Get up and practice your Ka'bah for a while!

When you take off your mask, be your own!

تصوير خدا بشت همين كهنه نقاب است

تصوير خذا واضح و جشمان نو خواب است نت 
CURRENT RESEARCH JOURNAL OF PHILOLOGICAL SCIENCES 2(9): 110-

116, September 2021

DOI: https://doi.org/10.37547/philological-crjps-02-09-24

ISSN 2767-3758

(C2021 Master Journals

Crossref do:

81 Google

Accepted25 $5^{\text {th }}$ September, 2021 \& Published 30 $30^{\text {th }}$ September, 2021

The image of God is behind this old mask

The image of God is clear, your eyes are asleep

شايد كه بتى در وسط ذهن من و توست بارت

بايد بت خود ، بانم بار ان خدا شنست

Maybe you and I are an idol in the middle of our minds

Need to wash this idol in the damp rain of God

كويى كه خدا در بدن و در تنمان هست

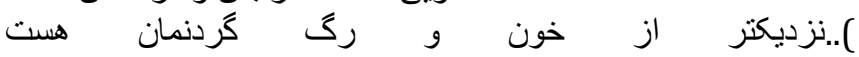

https://sedayedel.blog.ir/)

God is present in our body

The soul is even closer than our veins

Bedil, like Rumi, is a thinker who put forward the idea of purity, love, and striving for God in the essence of man. He believes that God is the source of light, but the light that leads to it is also man's inner light.

Muddao dil bud agar nayrangi imkon rextand, Bahri in yak qatra xun sad rangu to'fon rextand.

Meaning: As long as the world of opportunity - the material world - was created in different speeds and movements, the goal was the mind. They created a thousand colored floods for this one drop of blood. (Najmiddin Komilov. Sufism, 1996. - P.128)

Man is a divine being. He must live accordingly, that is, he must be engaged in good deeds, free from the cares of the world, and not be enslaved to all kinds of rituals and vain appearances. Then he realizes that the essence of faith, sect and religion is the same.

The thinker condemns discrimination on the basis of sect, nationality, religion, etc., in evaluating them in relation to people. He calls everyone to love people.

Yuz shukurki, turli dinu turlicha millat -

Odamlari uchraganda ko'rsatdim hurmat.

Soya kabi har tarafga bo'lsam-da ravon,

Yo'l ozig'im kishilarga bo'ldi muhabbat.

Meaning:

Thankfully, different religions and different nationalities -

I showed respect when people met.
I am fluent in all directions like a shadow, The way I fed people was love. (Mirza Abdulkadir Bedil. Rubaiyat. 1974: 80).

In Bedil's teaching, when the levels of humanity are determined by the levels of development of the soul, it means that spiritual superiority will inevitably prevail over oppression, cruelty, ignorance, and inferiority.

\section{Conclusion}

In his analysis of the essence of human, Bedil paid special attention to certain concepts of power, imitation, and religion. Strength plays a key role in a person's spiritual maturity and ascension. Imitation and religious fanaticism lead man to the abyss. There is no doubt that these wise words and exhortations in Bedil's short story will help to solve topical issues of educational significance even today.

\section{REFERENCES}

1. Boltaboev Hamidulla. Fitrat - bedilshunos. / Proceedings of the international conference "Bedil and Uzbek spirituality." - Tashkent: "Movarounnahr", Tehran: "Al-Hudo" International Publishing House, 2005. - Б.3453.

2. Komilov N. Sufism. - Tashkent: "Writer", 1996. - P. 270.

3. Komilov N. Sufism. Book 2. - Tashkent: "Literature and art", "Uzbekistan", 1999. - P. 207.

4. Ismail Bekjon. Bedil, inspired by Navoi. // "Literature and art of Uzbekistan", 2007. № 27. - P.4.

5. Matnazar Abdulhakim. Takallum. / Translation of Bedil rubai. - Nukus: Karakalpakstan,1995. - P. 62.

6. Matnazar Abdulhakim. Holy Visit 
CURRENT RESEARCH JOURNAL OF PHILOLOGICAL SCIENCES 2(9): 110-

116, September 2021

DOI: https://doi.org/10.37547/philological-crjps-02-09-24

ISSN 2767-3758

(C)2021 Master Journals

Crossref dof 81 Google

Accepted25 $5^{\text {th }}$ September, 2021 \& Published 30 ${ }^{\text {th }}$ September, 2021

Translation of Bedil's Rubaiyat. - Urgench:

Khorezm,1991. - P. 39.

7. Mirzo Abdulqadir Bedil. The Rubaiyat. /

Translated from Persian-Tajik by Sh.

Shomukhamedov. - Tashkent: "Literature and art", 1974. - P. 106.

8. Mirzo Abdulkodir Bedil. Ghazals and poems. Hijri 1333. - P. 118.

9. Mirzo Abdulqadir Bedil. Remembering your passion. - Tashkent: Publishing House,2005. - P. 144.

10. Mirzo Abdulqadir Bedil. Chor element.127

11. Muminov I. Mirza Bedil. - Tashkent: "Science",1964. - P. 76.

12. Shukurov Sh. The poetic legacy of Mirza Bedil. - Tashkent: "Science”,1979. - P. 132.

13. Farididdin Attor. Ilohiynoma / Translated from Persian by N.Kamilov. - Tashkent: "Writer",1994. - 94 б.

14. https://ziyouz.uz/jahon-sheriyati/fors-tojiksheriyati/mirzo-bedil/

15. https://sedayedel.blog.ir/1396/10/25/\%D8

\%B4\%D8\%B9\%D8\%B1\%DB\%8C-

$\% \mathrm{D} 8 \% \mathrm{~A} 7 \% \mathrm{D} 8 \% \mathrm{~B} 2-$

\%D9\%85\%D9\%88\%D9\%84\%D8\%A7\%D9\% 86\%D8\%A7

16. https://khdavron.uz/kutubxona/jahon/jafarmuhammad-abulmaoniy-manaviyati-bedilhayoti-va-falsafiy-qarashlariga-chizgilar.html 